\author{
Wojciech Klapsa ${ }^{a}{ }^{*}$, Daniel Małozięća) ${ }^{a}$ Damian Bąk \\ a) Scientific and Research Centre for Fire Protection - National Research Institute / Centrum Naukowo-Badawcze Ochrony \\ Przeciwpożarowej im. Józefa Tuliszkowskiego - Państwowy Instytut Badawczy \\ *Corresponding author / Autor korespondencyjny: wklapsa@cnbop.pl
}

\title{
Waste in the Context of Combustibility - Classification Possibilities in Legal Terms
}

\section{Odpady w kontekście palności - możliwości klasyfikacji w ujęciu prawnym}

\begin{abstract}
Purpose: The aim of the article is to review the possibility of classifying waste as non-combustible and combustible on the basis of the applicable Polish legal acts and to discuss the problems related to this area.

Introduction: In the last decade, there has been a marked increase in the number of fires in landfills in Poland. Therefore, a legislative initiative has been undertaken to tighten and complete the provisions of the law on fire protection of facilities and places where waste is collected and stored.

Methodology: The basic act regulating the issues of waste storage in Poland is the Act of 14 December 2012 on waste materials. The Act divides waste into two categories: non-combustible and combustible. In reference to the act, a Regulation of the Minister of the Interior and Administration of 19 February 2020 on fire protection requirements which need to be met by construction structures or their parts and other places for collecting, storing or processing waste, in which stringent fire safety requirements were defined for fire safety of facilities where combustible waste is stored.

Results: During the review and analysis of the legal acts, it was discovered that after the division into combustible and non-combustible waste, the classification rules for these two categories were not strictly defined. As a consequence, there was a problem of interpretation and, thus, discretion in classifying waste. Therefore, there was a need to review the knowledge on the possibility of classifying waste.

Conclusions: The review of regulations and the state of knowledge on the principles of considering materials and products as non-combustible or combustible presented in the article allows to systematize the knowledge and indicates selected paths of conduct. As waste is not homogeneous materials, the Act leaves the freedom to carry out opinions on whether or not waste is considered combustible. Such an assessment is not simple, hence the need to indicate what are the possible correct ways of proceeding in this action.

Keywords: combustible waste, non-combustible waste, waste classification, fire protection, landfills
\end{abstract}

Type of article: review article

Received: 29.06.2021; Reviewed: 13.07.2021; Accepted: 20.07.2021;

Authors' ORCID IDs: W. Klapsa - 0000-0002-6481-587X; D. Małozięć - 0000-0003-4929-8656; D. Bąk - 0000-0002-4438-358X.

Percentage contributon: W. Klapsa - 70\%; D. Małozięć - 20\%; D. Bąk - 10\%

Please cite as: SFT Vol. 57 Issue 1, 2021, pp. 42-48, https://doi.org/10.12845/sft.57.1.2021.3;

This is an open access article under the CC BY-SA 4.0 license (https://creativecommons.org/licenses/by-sa/4.0/).

\footnotetext{
ABSTRAKT

Cel: Celem artykułu jest przegląd możliwości klasyfikowania odpadów na niepalne i palne w oparciu o obowiązujące polskie akty prawne oraz omówienie problemów związanych z tym obszarem.

Wprowadzenie: W ostatniej dekadzie w Polsce nastąpił wyraźny wzrost liczby pożarów składowisk odpadów i wysypisk śmieci. W związku z tym została podjęta inicjatywa legislacyjna, aby zaostrzyć oraz uzupełnić przepisy prawa dotyczące ochrony przeciwpożarowej obiektów i miejsc, gdzie są gromadzone i przechowywane odpady.

Metodologia: Podstawowym aktem regulującym kwestie składowania odpadów w Polsce jest ustawa z dnia 14 grudnia 2012 r. o odpadach. W ustawie dokonano podziału odpadów na niepalne i palne. Co jest istotne dla problemu, nie określono ścisłych wymagań dla potrzeb klasyfikacji odpadów do tych dwóch kategorii. W nawiązaniu do ustawy opracowano rozporządzenie Ministra Spraw Wewnętrznych i Administracji z dnia 19 lutego 2020 r. w sprawie wymagań w zakresie ochrony przeciwpożarowej, jakie mają spełniać obiekty budowlane lub ich części oraz inne miejsca przeznaczone do zbierania, magazynowania lub przetwarzania odpadów, w którym określone zostały rygorystyczne wymagania w zakresie bezpieczeństwa pożarowego obiektów, w których składowane są odpady palne.

Wyniki: Podczas przeglądu i analizy aktów prawnych stwierdzono, że po dokonaniu podziału na odpady palne i niepalne nie określono ściśle zasad klasyfikacji do tych dwóch kategorii. W konsekwencji pojawił się problem interpretacji i - co za tym idzie - uznaniowości klasyfikowania odpadów. W związku z tym zaistniała potrzeba przeglądu wiedzy na temat możliwości klasyfikowania odpadów.
} 
Wnioski: Przedstawiony w artykule przegląd przepisów i stanu wiedzy na temat zasad uznawania materiałów i wyrobów za niepalne lub palne pozwala usystematyzować wiedzę oraz wskazuje wybrane ścieżki postępowania. Ponieważ odpady nie są materiałami jednorodnymi, ustawa pozostawia dobrowolność w zakresie wykonywania opinii dotyczących uznania odpadów za palne lub nie. Taka ocena nie jest prosta, stąd pojawiła się potrzeba wskazania, jakie są możliwe prawidłowe drogi postępowania w tym działaniu.

Słowa kluczowe: odpad palny, odpad niepalny, klasyfikacja odpadów, ochrona przeciwpożarowa, składowiska odpadów

Typ artykułu: artykuł przeglądowy

Przyjęty: 29.06.2021; Zrecenzowany: 13.07.2021; Zaakceptowany: 20.07.2021;

Identyfikatory ORCID autorów: W. Klapsa - 0000-0002-6481-587X; D. Małozięć - 0000-0003-4929-8656; D. Bąk - 0000-0002-4438-358X.

Procentowy wkład merytoryczny: W. Klapsa - 70\%; D. Małozięć - 20\%; D. Bąk - 10\%

Proszę cytować: SFT Vol. 57 Issue 1, 2021, pp. 42-48, https://doi.org/10.12845/sft.57.1.2021.3;

Artykuł udostępniany na licencji CC BY-SA 4.0 (https://creativecommons.org/licenses/by-sa/4.0/).

\section{Introduction}

Starting from 2011, the State Fire Service recorded a significant increase in the number of fires in landfills and waste dumps. In the years 2014-2016, over a thousand inspections were carried out, in which irregularities in the field of fire protection were found in approximately $45 \%$ of facilities where waste was stored [1]. Due to changes in legislation and the policy of waste management in Europe, more and more waste from abroad was sent to Poland. A large amount of imported waste from other countries and the permissible three-year time limit for their storage have resulted in self-ignition or setting on fire [2]. The analysis of the problem showed an urgent need for legislative changes.

As a result of the amendment to the Act on waste in 2018 [3], the obligation to prepare fire protection reports for waste storage sites was created. Pursuant to Art. $42 \mathrm{sec}$. $4 \mathrm{~b}$ of this Act, such a report is required as an attachment to the application for a permit to collect or process waste. The fire-fighting operation should include the conditions for fire protection of the installation, facility or part thereof or other waste storage place. This document should be agreed with the poviat or city commander of the State Fire Service.

In a situation where the application for a permit is directed to the voivodeship marshal or the regional environmental protection director, the survey should be prepared by a fire protection expert. However, when the application is to be considered by the starost, the persons who are authorized to prepare the survey should have a professional title of fire engineer or the professional title of engineer and a diploma of graduation from the Main School of Fire Service (in the field of safety engineering, specializing in fire safety engineering, issued by 30 September 2019) or studies in the field of safety engineering (in the field of fire safety issued after 30 September 2019).

\section{Non-combustible and combustible waste}

In the course of further analysis of waste regulations, an important aspect of determining the flammability or non-flammability of

\section{Wprowadzenie}

Począwszy od 2011 roku Państwowa Straż Pożarna odnotowała znaczący wzrost liczby pożarów na składowiskach odpadów i wysypiskach śmieci. W latach 2014-2016 wykonano ponad tysiąc kontroli, w których stwierdzono nieprawidłowości w zakresie ochrony przeciwpożarowej w ok. $45 \%$ obiektów, gdzie składowano odpady [1]. Zmiany prawa oraz polityka gospodarowania odpadami w Europie sprawiła, że do Polski trafiało coraz więcej odpadów z zagranicy. Duża ilość sprowadzonych odpadów z innych krajów oraz dopuszczalny trzyletni termin na ich składowanie spowodował, że opłacalnym sposobem na likwidację takich odpadów jest ich samozapłon lub podpalanie [2]. Analiza problemu wykazała pilną potrzebę wprowadzenia zmian legislacyjnych.

W wyniku zmiany z $2018 \mathrm{r}$. do ustawy o odpadach [3] powstał obowiązek opracowywania operatów przeciwpożarowych dla miejsc składowania odpadów. Zgodnie z art. 42 ust. $4 \mathrm{~b}$ tej ustawy taki operat jest wymagany jako załącznik do wniosku o zezwolenie na zbieranie odpadów lub ich przetwarzanie. Operat przeciwpożarowy powinien zawierać warunki ochrony przeciwpożarowej instalacji, obiektu lub jego części lub innego miejsca magazynowania odpadów. Dokument ten należy uzgodnić z komendantem powiatowym lub miejskim Państwowej Straży Pożarnej.

W sytuacji, gdy wniosek o zezwolenie jest kierowany do marszałka województwa albo regionalnego dyrektora ochrony środowiska, operat powinien być opracowany przez rzeczoznawcę do spraw zabezpieczeń przeciwpożarowych. Natomiast gdy wniosek przeznaczony jest do rozpatrzenia przez starostę, do przygotowania operatu uprawnione są osoby posiadające tytuł zawodowy inżyniera pożarnictwa lub tytuł zawodowy inżyniera oraz dyplom ukończenia studiów w Szkole Głównej Służby Pożarniczej (w zakresie inżynierii bezpieczeństwa, $w$ specjalności inżynierii bezpieczeństwa pożarowego, wydany do dnia 30 września 2019 r.) lub studiów na kierunku inżynierii bezpieczeństwa ( $w$ zakresie bezpieczeństwa pożarowego wydany po dniu 30 września 2019 r.).

\section{Odpady niepalne i palne}

W trakcie dalszej analizy przepisów dotyczących odpadów pojawia się istotny aspekt określenia palności lub niepalności odpadu. 
waste appears. The fire survey is not required for permits relating only to non-flammable waste and plants with an increased risk of a serious industrial accident or plants with a high risk of a serious industrial accident. On the basis of the delegation contained in art. $43 \mathrm{sec} .8$ of the Act on waste, the Minister of the Interior and Administration issued the Regulation of 19 February 2020 on fire protection requirements to be met by construction structures or their parts and other places for collecting, storing or processing waste [4]. The document defines detailed fire protection requirements for places with combustible waste.

Therefore, it seems that determining whether a given waste is non-combustible or combustible has become a key aspect for the application of certain statutory requirements. If we are dealing with combustible waste, we must take into account the necessity to meet more stringent requirements with regard to the places of their storage (which results from the provisions of the regulation [4]).

In order to classify waste into the appropriate group, i.e. non-combustible or combustible, first Annex 2a to the Act on waste should be applied. This Annex contains a non-exhaustive list of the categories of non-combustible waste. There are 15 categories of waste considered non-combustible. In addition to the categories mentioned above, non-combustible waste can be considered as non-combustible when it does not participate in the combustion process and does not affect the fire development and its power due to e.g. storage method, chemical composition or form, regardless of the waste code adopted for it. Assessment in this respect should be made individually, on a voluntary basis. At the same time, the provision of $\S 4$ point 1 of the regulation [4] indicates that all other waste that has not been classified as non-combustible in accordance with the Act [3] should be considered combustible waste. Due to the used definition, we cannot limit ourselves to substances defined as combustible on the basis of the classification of dangerous substances pursuant to Regulation (EC) No $1272 / 2008$ of the European Parliament and of the Council of 16 December 2008 on the classification, labeling and packaging of substances and mixtures, amending and repealing Directives 67/548/EEC and 1999/45/EC, and amending Regulation (EC) No 1907/2006 (CLP) [5]. The cited classification applies only to hazardous substances, but in principle the waste resulting from the processing of these substances is generally also considered hazardous.

Inverted definition of combustible waste and no indication of unambiguous criteria for classifying the waste into the appropriate group mean that a waste producer, which is not included in Annex 2 to the Act [3], must make an individual assessment. The classification issue can be approached intuitively on the basis of the physico-chemical properties of the materials or substances that make up the waste. In this way, it can be assumed that organic and other materials whose chemical composition allows combustion (oxidation) to generate energy, are considered flammable. Recognition of waste as a combustible material requires the application of many fire safety regulations regarding landfills resulting, among others, from the regulation [4].

When assessing waste in terms of flammability, it is possible to use other regulations that also define materials as
Operat przeciwpożarowy nie jest bowiem wymagany w stosunku do zezwoleń dotyczących wyłącznie odpadów niepalnych oraz zakładów o zwiększonym lub dużym ryzyku wystąpienia poważnej awarii przemysłowej. Na podstawie delegacji zawartej w art. 43 ust. 8 ustawy o odpadach Minister Spraw Wewnętrznych i Administracji wydał rozporządzenie z dnia 19 lutego 2020 r. w sprawie wymagań w zakresie ochrony przeciwpożarowej, jakie mają spełniać obiekty budowlane lub ich części oraz inne miejsca przeznaczone do zbierania, magazynowania lub przetwarzania odpadów [4]. Dokument określa szczegółowe wymagania z zakresu ochrony przeciwpożarowej dla miejsc, w których znajdują się palne odpady.

Wobec powyższego wydaje się, że kluczowym aspektem dla stosowania określonych wymagań ustawowych stało się ustalenie, czy dany odpad jest niepalny czy palny. Jeśli mamy do czynienia z odpadami palnymi, należy liczyć się z koniecznością spełnienia surowszych wymagań w odniesieniu do miejsc ich składowania (co wynika z zapisów rozporządzenia [4]).

W celu dokonania klasyfikacji odpadu do odpowiedniej grupy, tj. niepalny lub palny, w pierwszej kolejności należy posiłkować się załącznikiem nr 2a do ustawy o odpadach. Załącznik ten zawiera niewyczerpujący wykaz kategorii odpadów niepalnych. Znalazło się tam 15 kategorii odpadów uznawanych za niepalne. Poza wymienionymi kategoriami za niepalne można uznawać odpady, które nie biorą udziału w procesie spalania i nie wpływają na rozwój pożaru oraz jego moc ze względu na np. sposób magazynowania (składowania), skład chemiczny lub postać, niezależnie od przyjętego dla nich kodu odpadu. Oceny w tym zakresie należy dokonać indywidualnie, na zasadzie dobrowolności. Jednocześnie zapis $\S 4$ pkt. 1 rozporządzenia [4] wskazuje, że wszystkie inne odpady, które nie zostały zgodnie z ustawą [3] sklasyfikowane jako niepalne, należy uznać za palne. Z uwagi na zastosowaną definicję nie można ograniczyć się jedynie do substancji określanych jako palne na podstawie klasyfikacji substancji niebezpiecznych wynikającej z rozporządzenia Parlamentu Europejskiego i Rady (WE) NR 1272/2008 z dnia 16 grudnia 2008 r. w sprawie klasyfikacji, oznakowania i pakowania substancji i mieszanin, zmieniające i uchylające dyrektywy 67/548/EWG i 1999/45/WE oraz zmieniające rozporządzenie (WE) nr 1907/2006 (CLP) [5]. Przywołana klasyfikacja dotyczy jedynie substancji niebezpiecznych, ale w zasadzie odpady powstałe $w$ wyniku przetwarzania tych substancji z reguły również są uznawane za niebezpieczne.

Odwrócona definicja odpadów palnych oraz brak wskazania jednoznacznych kryteriów klasyfikujących odpad do odpowiedniej grupy powoduje, że wytwórca odpadu, którego nie ujęto w załączniku nr 2 do ustawy [3], musi dokonać indywidualnej oceny. Intuicyjnie można podejść do kwestii klasyfikacyjnej na podstawie właściwości fizyko-chemicznych materiałów lub substancji, z jakich składa się odpad. W ten sposób można założyć, że materiały organiczne i inne, których skład chemiczny pozwala na spalanie (utlenianie się) $z$ wytworzeniem energii, uznamy za palne. Uznanie odpadu za materiał palny wiąże się z koniecznością zastosowania wielu przepisów bezpieczeństwa pożarowego dotyczącego składowisk odpadów wynikających $\mathrm{m}$. in. z rozporządzenia [4].

Przy dokonywaniu oceny odpadu pod względem palności istnieje możliwość posiłkowania się innymi przepisami, które 
non-combustible. From the point of view of a fire threat and its assessment, the Polish Standard PN-B-02852 [6] comes first. The standard specifies the method of calculating the fire load density resulting from the combustion of combustible materials in the fire zone. Based on its records, the following can be considered as non-combustible materials:

- contained in fireproof containers, trays and packages,

- immersed in water and aqueous solutions,

- with a water content of more than $60 \%$.

In the process of the classification in question, one can also rely on the regulation of the Minister of Infrastructure on the technical conditions to be met by buildings and their location [7]. Annex 3 to this document defines the relationship between the hitherto descriptive classification and the Eroklas system. In accordance with the provisions in the table, as non-combustible are materials belonging to one of the following classes: $A 1 ; A 2-s 1, d 0$; A2-s2, $\mathrm{d} 0 ; A 2-\mathrm{s} 3, \mathrm{~d} 0 ; A 1_{\mathrm{fl}} ; A 2_{\mathrm{fl}}-\mathrm{s} 1 ; A 2_{\mathrm{fl}}-\mathrm{s} 2$ [8]. Standardized test methods have been assigned to the individual requirements. The basis for the classification is the PN-EN 13501-1 standard [9], which indicates the methods and criteria for classifying construction products into appropriate classes [10]. In each case, there are two methods, one of which concerns the heat of combustion test according to PN-EN ISO 1716 [11], and the other one is selected depending on the class and type of the tested material. However, these are expensive tests and - in case of waste - they are often problematic to be performed (there is a significant problem with the preparation of an appropriate sample for testing). For this reason, we often encounter a situation where people who carry out fire operations consider waste as non-combustible where the heat of combustion is below $3 \mathrm{MJ} / \mathrm{kg}$ (value for the entire product). It is a value defined in the classification standard [9] as the limit for class A2. However, such an assumption without proper analysis of the impact of the material on the fire hazard of the landfill is not entirely appropriate in accordance with the Act [3]. Also, formally, the product does not meet the definition of a non-combustible material according to the regulation [7], because the full classification according to the standard [9] has not been performed. It is also possible to classify products into appropriate classes of reaction to fire on the basis of the decisions of the European Commission concerning fire classification, which are published in the Official Journal of the European Union. An example is the decision of 26 September 2000 (2000/605/EC), which lists materials in classes $A 1$ and $A 1_{\mathrm{fl}}$ [12].

The greatest challenge is the classification of mixed waste. The most common example of such waste is construction and demolition waste, from which it is impossible to separate wood and plastic waste. In this case, Art. 3b of the Act [3] should be used and an individual assessment of the impact of the collected waste and the method of storage on the fire hazard should be made. At the same time, it should be noted that the inert waste catalog [13] also allows for a certain low content of wood and plastic in construction and demolition waste. In this case, the evaluator is obviously unable to conclude that these materials are non-combustible. As a result, the opinion should show that the content of these materials does not contribute to the spreading and development of the fire and does not substantially affect the power of the fire. również definiują materiały jako niepalne. Z punktu widzenia zagrożenia pożarowego i jego oceny, jako pierwsza nasuwa się Polska Norma PN-B-02852 [6]. W normie określono sposób obliczania gęstości obciążenia ogniowego w wyniku spalania się materiałów palnych znajdujących się w strefie pożarowej. W oparciu o jej zapisy można uznać za niepalne materiały:

- znajdujące się w ognioodpornych pojemnikach, zasobnikach i opakowaniach,

- zanurzone w wodzie i roztworach wodnych,

- o zawartości wody ponad $60 \%$.

W procesie omawianej klasyfikacji można również oprzeć się na rozporządzeniu Ministra Infrastruktury w sprawie warunków technicznych, jakim powinny odpowiadać budynki i ich usytuowanie [7]. W załączniku nr 3 do tego dokumentu określono relacje pomiędzy dotychczasową klasyfikacją opisową i systemem Eroklas. Zgodnie z zapisami zawartymi w tabeli za niepalne uznaje się materiały zaliczane do jednej $z$ wymienionych klas: $A 1$; $A 2-s 1, d 0 ; A 2-s 2, d 0 ; A 2-s 3, d 0 ; A 1_{f l} A 2_{f l}-s 1 ; A 2_{f 1}-s 2$ [8]. Do poszczególnych wymagań zostały przypisane znormalizowane metody badań. Podstawę do klasyfikacji stanowi norma PN-EN 13501-1 [9], w której wskazano metody i kryteria do klasyfikacji wyrobów budowlanych do odpowiednich klas [10]. W każdym przypadku są to dwie metody, z czego jedna dotyczy badania ciepła spalania wg PN-EN ISO 1716 [11], a druga dobierana jest w zależności od klasy i rodzaju badanego materiału. Są to jednak badania kosztowne oraz - w przypadku odpadów - nierzadko problematyczne do wykonania (występuje istotny problem z przygotowaniem odpowiedniej próbki do badań). Z tego powodu spotykamy się często z sytuacją, że osoby wykonujące operaty pożarowe uznają za niepalne odpady, których ciepło spalania jest poniżej $3 \mathrm{MJ} / \mathrm{kg}$ (wartość dla całego wyrobu). Jest to wartość określona w normie klasyfikacyjnej [9] jako graniczna dla klasy A2. Jednak takie założenie bez wykonania odpowiedniej analizy wpływu materiału na zagrożenie pożarowe składowiska nie jest do końca właściwe i zgodne z ustawą [3]. Także formalnie wyrób nie spełnia definicji materiału niepalnego w myśl rozporządzenia [7], ponieważ nie została wykonana pełna klasyfikacja zgodnie z normą [9]. Istnieje również możliwość klasyfikowania wyrobów do odpowiednich klas reakcji na ogień na podstawie decyzji Komisji Europejskiej dotyczących klasyfikacji ogniowej, które publikowane są w Dzienniku Urzędowym Unii Europejskiej. Jako przykład może służyć decyzja z dnia 26 września 2000 r. (2000/605/WE), gdzie wymieniono materiały w klasie $\mathrm{A} 1$ i $\mathrm{A}_{\mathrm{fl}}$ [12].

Największe wyzwanie stanowi klasyfikacja odpadów zmieszanych. Najczęściej spotykanym przykładem takiego odpadu są odpady budowlano-rozbiórkowe, z których nie można wyodrębnić (oddzielić) odpadów z drewna i tworzyw sztucznych. W tym przypadku należy skorzystać z art. 3b ustawy [3] i dokonać indywidualnej oceny wpływu zgromadzonych odpadów i sposobu składowania na zagrożenie pożarowe. Jednocześnie należy zwrócić uwagę, że katalog odpadów obojętnych [13] również dopuszcza pewną niską zawartość drewna i tworzyw sztucznych w odpadach budowlanych i rozbiórkowych. W tym przypadku osoba dokonująca oceny oczywiście nie jest w stanie stwierdzić, że te materiały są niepalne. W rezultacie opinia powinna wykazać, że 
An extremely useful solution in the process of determining the combustibility or non-combustibility of waste is the possibility of approving the opinion of research institutes or scientific centers [3] specializing in testing the fire properties of products and materials. These units have significant knowledge and experience in the field of flammability of various materials and their potential fire behavior. An additional advantage of this solution is the possibility of performing other necessary tests that will give a broader view on the flammability of the tested waste.

In addition to the basic test - the previously mentioned determination of the heat of combustion - it is possible to assess the susceptibility of a substance (sample) to ignition by determining the ignition or ignition temperature and to assess the possibility of the spread of combustion. An example of this type of activity can be the study of the flammability of waste from rainwater sewage, collected, among others in sedimentation tanks and sand traps, which were carried out at CNBOP-PIB Laboratory of Combustion Processes and Explosions. This waste is normally present in a hydrated form, but the water content - due to the open storage of the material - changes depending on the current weather conditions, which in turn may lead to the evaporation of water and the appearance of sludge in a dried form. Thus, there may be different states of hydration as a function of the waste storage time. Dried waste will pose the greatest threat. The carried out study of the heat of combustion for the dried material gave an average result of $1.01 \mathrm{MJ} / \mathrm{kg}$ with the determined moisture content of $4.31 \%$ [14]. Additional flash point tests gave a result of more than $200^{\circ} \mathrm{C}$. When assessing the flammability, it was found that the ignition of the sample is not long-lasting. Careful evaluation of material residues after the combustion heat test showed that a large part of the unburned residues were non-combustible materials such as sand or small stones. Taking into account the collected information from the entire research process, it was found that waste with such composition and storage methods can be considered non-combustible and does not significantly contribute to the fire growth.

Due to no clearly defined classification criteria allowing for unambiguous determination of combustibility or non-combustibility of waste, after analyzing numerous test methods in the field of material flammability assessment, CNBOP-PIB staff paid attention to the methodology described in PN-EN 16733-2016-06 standard Reaction to fire tests of construction products - Determination of the susceptibility of a construction product to the process of continuous smoldering [16]. This standard specifies a test method for determining the tendency (ability) of a construction product to continually smolder when exposed to an open flame under the influence of natural, convective air flow. It is a method used to further evaluate building materials classified in accordance with PN-EN 13501-1. It allows to assess the tendency of the tested sample to the long-term duration of internal combustion in the form of oxygen. The sample is subjected to a burner, and then it is checked whether there is a temperature increase inside the sample. Based on the above method, after introducing a few modifications taking into account the specificity of waste, the authors of this article developed a flammability zawartość tych materiałów nie przyczynia się do rozprzestrzeniania i rozwoju pożaru oraz nie wpływa zasadniczo na moc pożaru.

Niezwykle przydatnym rozwiązaniem w procesie określania palności lub niepalności odpadów jest możliwość dopuszczenia w tym zakresie opinii instytutów badawczych lub ośrodków naukowych [3] specjalizujących się w badaniach właściwości ogniowych wyrobów i materiałów. Jednostki te dysponują znaczącą wiedzą i doświadczeniem w obszarze palności różnych materiałów i ich potencjalnego zachowania podczas pożaru. Dodatkowym atutem tego rozwiązania jest możliwość wykonania innych niezbędnych testów, które dadzą szerszy pogląd na temat palności badanego odpadu.

Oprócz podstawowego badania - już wcześniej wspomnianego określenia ciepła spalania - można dokonać oceny podatności substancji (próbki) na zapalenie poprzez wyznaczenie temperatury zapalenia lub zapłonu oraz przeprowadzić ocenę możliwości rozprzestrzeniania się spalania. Za przykład tego typu działań może posłużyć badanie palności odpadu z kanalizacji deszczowej, gromadzonego $\mathrm{m}$. in. w osadnikach i piaskownikach, które wykonano w Zespole Laboratoriów Procesów Spalania i Wybuchowości CNBOP-PIB. Odpad ten w normalnych warunkach występuje w postaci uwodnionej, jednak zawartość wody - za sprawą otwartego składowania materiału - zmienia się w zależności od aktualnie panujących warunków atmosferycznych, co w konsekwencji może doprowadzić do odparowania wody i pojawienia się osadu w formie wysuszonej. Mogą więc występować różne stany uwodnienia w funkcji czasu składowania odpadu. Największe zagrożenie będzie stanowił odpad w postaci wysuszonej. Przeprowadzone badanie ciepła spalania dla materiału wysuszonego dało wynik średni na poziomie 1,01 MJ/kg przy oznaczonej wilgotności 4,31\% [14]. Dodatkowe badania temperatury zapłonu dały wynik o wartości powyżej $200^{\circ} \mathrm{C}$. Oceniając zapalność stwierdzono, że zapłon próbki nie jest długotrwały. Wnikliwa ocena pozostałości materiału po badaniu ciepła spalania wykazała, że dużą część niespalonych resztek stanowiły materiały niepalne, takie jak piasek czy drobne kamienie. Mając na uwadze zgromadzone informacje z całego procesu prowadzonych badań uznano, że odpad o takim składzie i sposobie przechowywania można uznać za niepalny oraz nieprzyczyniający się istotnie do wzrostu pożaru.

W związku z brakiem jednoznacznie określonych kryteriów klasyfikacyjnych, pozwalających na jednoznaczne określanie palności lub niepalności odpadów, po analizie licznych metod badawczych w zakresie oceny palności materiałów personel CNBOP-PIB zwrócił uwagę na metodykę opisaną w normie PN-EN 16733-2016-06 Badania reakcji na ogień wyrobów budowlanych - Oznaczanie podatności wyrobu budowlanego na przechodzenie w proces ciągłego tlenia [16]. W niniejszej normie podano metodę badania do oznaczenia skłonności (zdolności) wyrobu budowlanego do ciągłego tlenia po wystawieniu na działanie otwartego płomienia pod wpływem naturalnego, konwekcyjnego przepływu powietrza. Jest to metoda stosowana do dalszej oceny materiałów budowlanych klasyfikowanych zgodnie z PN-EN 13501-1. Pozwala ona na ocenę tendencji badanej próbki do długotrwałego utrzymywania się palenia wewnętrznego w postaci tlenia. Próbkę poddaje się oddziaływaniu palnika, po czym sprawdza się, czy następuje 
assessment methodology adapted to various types of solid waste. After full verification, it will be implemented in everyday research and service activities.

\section{Summary}

As a result of the increase in the number of actual fires in landfills, the legislator tightened the provisions on fire protection conditions for waste collection sites. Most of them relate directly to the places where combustible waste is deposited. From the chemical point of view, the materials and substances that surround us are mainly combustible materials. The specificity of collecting waste does not allow for an unambiguous separation of individual materials, which means that most of the waste is mixed waste. The second important issue is the possibility of reducing the investment costs related to the processing and storage of waste, which often requires a practical approach to the issue of fire risk assessment. Therefore, on the one hand, a reliable and thorough assessment of the flammability of a given waste can reduce the costs of waste collection, and, allows to maintain an appropriate level of fire safety, which was the main goal of the change in regulations. In the absence of clearly defined classification criteria, there is some voluntariness in this regard, which, however, should be supported by knowledge and experience.

\section{Literature / Literatura}

[1] Janik P., Palący problem, „Przegląd Pożarniczy” 2018, 7, 13-15.

[2] Cygańczuk K., Janik P., Bezpieczeństwo środowiskowe a uregulowania prawne w gospodarce odpadami, „Przemysł Chemiczny" 2020, 99 (7), 970-976, https://doi.org/ 10.15199/62.2020.7.1.

[3] Ustawa z dnia 14 grudnia 2012 r. o odpadach (tekst jednolity Dz. U. z 2021 r. poz. 779, 784).

[4] Rozporządzenie MSWiA z dnia 19 lutego 2020 r. w sprawie wymagań w zakresie ochrony przeciwpożarowej, jakie mają spełniać obiekty budowlane lub ich części (Dz. U. poz. 296).

[5] Rozporządzenie Parlamentu Europejskiego i Rady (WE) NR 1272/2008 z dnia 16 grudnia 2008 r. w sprawie klasyfikacji, oznakowania i pakowania substancji i mieszanin, zmieniające i uchylające dyrektywy 67/548/EWG i 1999/45/WE oraz zmieniające rozporządzenie (WE) nr 1907/2006 (CLP). wzrost temperatury wewnątrz próbki. W oparciu o powyższą metodę, po wprowadzeniu kilku modyfikacji uwzględniających specyfikę odpadów, autorzy niniejszego artykułu opracowali metodykę oceny palności dostosowaną do różnego rodzaju odpadów stałych. Po pełnej weryfikacji zostanie ona wdrożona w codziennej działalności badawczej i usługowej.

\section{Podsumowanie}

W wyniku wzrostu liczby rzeczywistych pożarów na składowiskach odpadów ustawodawca dokonał zaostrzenia przepisów odnośnie warunków ochrony przeciwpożarowej dla miejsc gromadzenia odpadów. Większość z nich dotyczy bezpośrednio miejsc składowania odpadów palnych. Otaczające nas materiały i substancje, z punktu widzenia chemicznego, to głównie materiały palne. Specyfika gromadzenia odpadów nie pozwala na jednoznaczne oddzielenie poszczególnych materiałów, co sprawia, że większość odpadów to odpady zmieszane. Drugą istotną kwestią jest możliwość ograniczenia kosztów inwestycji związanej z przetwarzaniem i składowaniem odpadów, co często wymaga praktycznego podejścia do kwestii oceny zagrożenia pożarowego. Dlatego rzetelna i wnikliwa ocena palności danego odpadu $z$ jednej strony może pozwolić na ograniczenie kosztów gromadzenia odpadów, a z drugiej - na zachowanie odpowiedniego poziomu bezpieczeństwa pożarowego, co było głównym celem zmiany przepisów. Przy braku jednoznacznie określonych kryteriów klasyfikacyjnych pozostaje w tym względzie pewna dobrowolność, która jednak powinna być poparta wiedzą i doświadczeniem.
[6] PN-B-02852:2001 Ochrona przeciwpożarowa budynków. Obliczanie gęstości obciążenia ogniowego oraz wyznaczanie względnego czasu trwania pożaru.

[7] Rozporządzenia Ministra Infrastruktury z dnia 12 kwietnia 2002 r. w sprawie warunków technicznych, jakim powinny odpowiadać budynki i ich usytuowanie (Dz. U. z 2019 r. poz. 1065 z późn. zm.).

[8] Małozięć D., Koniuch A., Reakcja na ogień metody badań i kryteria klasyfikacji, BiTP Vol. 17 Issue 1, 2010, pp. 63-74,

[9] PN-EN 13501-1:2019-02 Klasyfikacja ogniowa wyrobów budowlanych i elementów budynków - Część 1: Klasyfikacja na podstawie badań reakcji na ogień.

[10] Porowski R., Małozięć D., Naukowe metody wspomagające proces ustalania przyczyn powstawania pożarów w: Czerwona księga pożarów, Guzewski P., Wróblewski D., Małozięć D. (red.), tom 2, Wydawnictwo CNBOP-PIB, Józefów 2014, 151-209. 
[11] PN-EN ISO 1716:2018-08 Badania reakcji na ogień wyrobów - Określanie ciepła spalania brutto (wartości kalorycznej).

[12] Decyzja z dnia 04.10.1996 (96/603/WE) zmieniona decyzją $z$ dnia 26.09.2000 (2000/605/WE).

[13] Rozporządzenie Ministra Gospodarki z dnia 16 lipca 2015 r. w sprawie dopuszczania odpadów do składowania na składowiskach (Dz. U. z 2015 r. poz. 1277).
[14] Opinia Zespołu Laboratoriów Procesów Spalania i Wybuchowości CNBOP-PIB dot.: Określenia cechy palności odpadu z kanalizacji deszczowej nr 270/BW/20, Józefów 2020.

[15] PN-EN 16733-2016-06 Badania reakcji na ogień wyrobów budowlanych - Oznaczanie podatności wyrobu budowlanego na przechodzenie w proces ciągłego tlenia.
BRIG. WOJCIECH KLAPSA, M.SC. ENG. - a graduate of the Main School of Fire Service in Warsaw and the Military University of Technology in Warsaw, Faculty of Chemistry. Currently, he serves at Centrum Naukowo-Badawcze Ochrony Przeciwpożarowej - Państwowy Instytut Badawczy in the Laboratory of Combustion Processes and Explosions as a manager. Author or co-author of articles on fire safety and flammable properties of building materials. At CNBOP$\mathrm{PIB}$, he deals with the subject of technical expertise of buildings, court opinions in the field of determining the causes of fires and research in the field of reaction to fire of construction products, as well as determining the explosive parameters of flammable substances. A speaker at national and international conferences, as well as a lecturer during exercises, workshops and training during training courses and other courses.

SENIOR BRIG. DANIEL MAŁOZIĘĆ, M.SC. ENG. - a graduate of the Main School of Fire Service in Warsaw. A long-time manager in the Laboratory of Combustion Processes and Explosions at Centrum Naukowo-Badawcze Ochrony Przeciwpożarowej - Państwowy Instytut Badawczy. Currently, he is the Deputy Director for Research and Development at CNBOP-PIB. Author of numerous articles on fire safety, flammable properties of construction materials and many expert opinions related to determining the causes of fires.

DAMIAN BĄK, ENG. - a graduate of the Faculty of Production Engineering at the Warsaw University of Technology, majoring in Mechanics and Machine Construction, currently completing his master's studies in the field of Management and Globalized Production Engineering at the same university. He works as a specialist in the Laboratory of Combustion Processes and Explosions at Centrum Naukowo-Badawcze Ochrony Przeciwpożarowej - Państwowy Instytut Badawczy in Józefów.
MŁ. BRYG. MGR INŻ. WOJCIECH KLAPSA - absolwent Szkoły Głównej Służby Pożarniczej w Warszawie i Wojskowej Akademii Technicznej w Warszawie Wydziału Chemii. Obecnie pełni służbę w Centrum Naukowo-Badawczym Ochrony Przeciwpożarowej - Państwowym Instytucie Badawczym w Zespole Laboratoriów Procesów Spalania i Wybuchowości na stanowisku Kierownika. Autor lub współautor artykułów o tematyce bezpieczeństwa pożarowego oraz właściwości palnych materiałów budowlanych. W CNBOP-PIB zajmuje się tematyką ekspertyz technicznych budynków, opinii sądowych w zakresie ustalania przyczyn pożarów oraz badaniami w zakresie reakcji na ogień wyrobów budowlanych, a także wyznaczaniem parametrów wybuchowych substancji palnych. Prelegent na konferencjach krajowych i zagranicznych, a także wykładowca podczas ćwiczeń oraz warsztatów i treningów na szkoleniach i kursach.

ST. BRYG. MGR INŻ. DANIEL MAŁOZIĘĆ - absolwent Szkoły Głównej Służby Pożarniczej w Warszawie. Wieloletni kierownik w Zespole Laboratoriów Procesów Spalania i Wybuchowości w Centrum Naukowo-Badawczym Ochrony Przeciwpożarowej - Państwowym Instytucie Badawczym. Obecnie pełni funkcję Zastępcy Dyrektora ds. Badań i Rozwoju w CNBOP-PIB. Autor licznych artykułów o tematyce bezpieczeństwa pożarowego, właściwości palnych materiatów budowlanych oraz wielu ekspertyz związanych z ustalaniem przyczyn pożarów.

INŻ. DAMIAN BĄK - absolwent Wydziału Inżynierii Produkcji na Politechnice Warszawskiej, kierunek Mechanika i Budowa Maszyn, obecnie kończy studia magisterskie na kierunku Zarządzanie i Inżynieria Produkcji Zglobalizowanej na tej samej uczelni. Pracuje na stanowisku specjalisty w Zespole Laboratoriów Procesów Spalania i Wybuchowości w Centrum Naukowo-Badawczym Ochrony Przeciwpożarowej - Państwowym Instytucie Badawczym w Józefowie. 